\title{
THE IMPACT OF CASH CONVERSION CYCLE ON FINANCIAL DISTRESS WITH PROFITABILITY AS A MODERATING VARIABLE
}

\author{
Fitratul Firda Amaliah") Arif Darmawan ${ }^{2}{ }^{\text {** }}$ \\ Management Accounting Program, Politeknik Negeri Batam \\ 1) E-mail: fitratul.firda.amaliah@gmail.com \\ Management Accounting Program, Politeknik Negeri Batam \\ 2) E-mail: darmawan@polibatam.ac.id
}

\begin{abstract}
This study aims to provide empirical evidence on the impact of profitability on the correlation cash conversion cycle to financial distress. The population in this study is a manufacturing company listed on the Indonesia Stock Exchange period 2010 to 2016 with a total sample of 9 companies. The sample collection method using purposive sampling and the testing measurement used was regression analysis. The result of this study proves that the cash conversion cycle affect positive to financial distress and profitability able to moderate the relationship between the cash conversion cycle to financial distress.
\end{abstract}

Keywords: Cash Conversion Cycle, Profitability, Financial Distress 


\section{INTRODUCTION}

The global financial crisis in late 2008 led to a sharp decline in economic growth in some developed countries, particularly the United States as the epicenter of the crisis triggered by high-risk housing credit crunch the US(subprime). The slowing economic activity in developed countries has affected the developing countries, especially those with close trade and financial ties with developed countries, including Indonesia. The impact of this global crisis will of course affect the survival of the company. Looking at the phenomenon, investors and potential investors will be more careful in instilling their shares.Through the analysis of the financial statements of investors and prospective investors can see the potential for corporate survival and potential bankruptcy. Knowing the prediction of company survival is also very important for the management and owners of the company to know the company's financial condition and anticipate conditions that could lead to potential bankruptcy. Before the company goes bankrupt, it will go through a period known financial distress.

Financial distress is defined as a condition in which the company has decreased the financial condition prior to the bankruptcy, one of the characteristics of companies that distress has a net operating negative for two consecutive years (Almilia and Silvy, 2003; Almilia and Kristijadi, 2003; Almilia, 2006; Widarjo and Setiawan, 2009). When the company suffers continuous operating losses causing capital deficiency. If this is allowed to drag on then it will cause the company to go bankrupt. While the research conducted by Almilia (2003) defines firms in financial distress when the company suffered delisted due to negative operating profit, the book value of negative equity and mergers.

One important aspect of the availability of working capital is cash. The availability of capital will be greatly influenced by the cash flow within the company. The Company started its business operations by purchasing raw materials, then processed into finished materials. At the time of buying the raw materials, if the payment is made with cash, then there is cash out of the company. If paid with credit, the company has a trade debt. Such trade payable can delay cash payments. Then the finished goods are sold with credit, which means the company has accounts receivable. At the time the accounts receivable are repaid, the company will get the cash back. This operational activity illustrates how the cash conversion cycle (CCC) occurs, which is issued by the company and will eventually return to the company (Hanafi, 2004).

Jordan and Jordan (2013) state that CCC is an important metric in companies that rely heavily on cash management policies. Cash management decision is a very important decision considering cash is the most liquid assets to be used in the company's operations. The existence of cash will greatly affect the performance of the company to compete in the market. Cash management policies and procedures depend on the company's financial situation and should be consistent with competitors' policies in the market so that the company can compete and survive.

Research on the effects of the Cash Conversion Cycle (CCC) on the performance of the company and the management of working capital has been done by several researchers including by Benardi and Bakara (2012), which uses a variable CCC presents an analysis of the parameters Days

Sales

Outstanding (DSO), Days Inventory Outstanding (DIO) and Days Payable Outstanding (DPO) in the mobile telecommunications operator open company shows there is a strong positive correlation between the Cash Conversion Cycle (CCC), Return on Assets (ROA) 
and Return on Equity (ROE). Ebben and Jhonson (2011) in his research analyzed the relationship between CCC and invested capital, liquidity, and firm performance reflecting significant relationships. Past research has examined the influence of the CCC more related to capital management on corporate performance (profitability) as done by Madugba and Ogbonnaya (2016), Kamau and Ayuo (2014), Gul, et al.(2010), as well as Yazdanfar and Ohman (2014) shows the duration of CCC has a significant effect on company performance.

The company's survival can be seen from the company's financial condition. One indicator that could be a benchmark is whether the company is in good health or in financial distress. Companies that are in financial distress showed a decrease in financial conditions continue to deteriorate if it is likely to face bankruptcy. Previous research has found various indicators in predicting financial distress. Almilia and Kristijadi (2003) and Widardjo and Setiawan (2009) found that the most dominant financial ratios to predict financial distress is the ratio of profitability, financial leverage, liquidity ratios and growth ratios. Almilia (2006) again tried to test the prediction of financial distress companies go public using logit multinominal analysis and research shows that the ratio could be used to predict a company's financial distress.

Much of the literature which show that the cash conversion cycle ofnegative effect on profitability. The longer the level of cash conversion cycle within a company shows lower levels of profitability. Several studies of financial distress in a company shows that the company's profitability affect the probability of financial distress, where profitability has a negative influence on financial distress. The lower profitability of the company, the more it will allow companies

experiencing financial distress. From the results of research related to the cash conversion cycle and financial distress indicate that there will be the effect on the cash conversion cycle of financial distress in relation to the level of profitability of the company. This suggests that profitability could be moderating the relationship between the cash conversion cycle to financial distress.

Based on the background of the problem and the results of previous studies, the researcher is interested in doing research on the development of the results of research conducted by Yazdanfar and Ohman (2014) and Widarjo and Setiawan (2009) with the title "The Impact of Cash Conversion Cycle on Financial Distress With Profitability As Moderating Variable ".

\section{LITERATURE} Signaling Theory

Ross (1977) developed a model that capital structure (use of debt) is used as the signal delivered by the manager to the market. The manager will give a signal that is more reliable (credible) using debt indicators. Greater debt level indicates the company is confident in the company's prospects in the future and be a positive signal. When managers have confidence that the company's prospects are good, then a manager will tend to communicate that to investors. This is done with the aim to attract investors to conduct investment activities.

\section{Agency Theory}

Agency theory by Jensen and Mecklin (1976) defines the agency theory as the relationship between the agent (management company) and the principal (capital owner or owners of the company). In the agency relationship there is a contract in which the principal gives the task the agent to perform a service on behalf of the principal and authorized the agent to make the best decisions for the principal. Principal employs an agent to perform tasks related to company operations including economic decision making, not least when the company in financial 
distress. Agent as a manager will make decisions for various strategies in order to maintain the company's business continuity.

\section{Cash Conversion Cycle and Profitability}

Ebben and Johnson (2011) examine the relationship between $\mathrm{CCCs}$ against liquidity levels, invested capital, and performance in small firms over time over the period 2002-2004. In a sample of 879 small US manufacturing firms and 833 small US retail companies, the CCC is significantly linked to these three aspects. Companies with more efficient CCCs exhibit more liquid corporate circumstances, lower debt levels, smaller equity financing and higher returns on capital.

Yazdanfar and Ohman (2014) tested the impact of the duration of the CCC or cash conversion cycle on profitability in small and medium-sized companies in Sweden. Samples taken consisting of 13,797 eligible small and medium enterprises can be used as panel data in the period 20082011. This study found that working capital plays an important role in the formation of profitability and competitiveness of enterprises. CCC as a proxy of working capital management significantly influence profitability, the longer the CCC or the cash conversion cycle will further reduce the company's profitability.

\section{Profitability and Financial Distress}

Research conducted by Widarjo and Setiawan (2009) aims to determine how much influence the variable liquidity ratios, profitability, financial leverage and sales growth (sales growth) in predicting the condition of the company said to be in financial distress that enables the company to bankruptcy. In this study, the company used as an object of research is the company's Automotive and Allied Products. The results showed liquidity as measured by the current ratio and cash ratio, financial leverage as measured by total liabilities to total assets and current liabilities to total assets, as well as sales growth did not affect the company's financial distress. On the other hand, liquidity is measured by the quick ratio and profitability have a negative influence on financial distress.

Saleh and Sudiyanto (2013) analyzed the influence of Current Ratio (CR), Debt Ratio (DR), Total Asset Turnover Ratio (TATR), Return on Assets (ROA) and Return on Equity (ROE) on the probability of bankruptcy. The object of this research is a manufacturing company listed on Indonesia Stock Exchange during 20082012. Results showed that the Current Ratio and Total Asset Turnover Ratio can not predict the occurrence probability of bankruptcy in manufacturing companies, while Debt Ratio, Return on Assets and Return on Equity can predict the occurrence probability of bankruptcy on manufacturing companies listed in Indonesia Stock Exchange. Low ROA and ROE indicate the company's low ability to profit from the use of assets and equity, or the use of assets and equity that are not maximal, so that will result in the occurrence probability of bankruptcy.

\section{Hypotheses}

\section{The Effect of Cash Conversion Cycle to Financial Distress}

Management of working capital related to the management of current assets, cash, accounts receivable and inventory. This relates to the company's operating cycle when the firm buys inventory, sells merchandise on credit, and then charges its receivables. This cycle is called a cash conversion cycle that focuses on the time range that occurs when a company receives payments and receives cash inflows. A good working capital policy is designed to minimize the time between cash expenditures for raw materials and cash collection from sales called CCCs. Company goals shorten the $\mathrm{CCC}$ to 
increase profitability because the longer the CCC will be the higher the need for external funding and the greater the costs required.

A wrong decision on capital structure will result in high capital costs and the possibility of occurrence of a financial distress (Murhadi, 2013). Besides, according to agency theory is the duty of the company operations agent.Therefore, agents are required to be able to optimize existing capital to improve profitability. Companies that have a high profit, it can be said that the agent managed to take the best decisions in the management of the company.With high profit would be a positive signal to investors so as to attract investors to invest in the company, so the chances of companies experiencing financial distress will be smaller. The longer the CCC indicates a less effective capital turnover. This shows that the longer the CCC will increase the probability of companies experiencing financial distress. Based on the above description then the hypothesis to be tested as follows:

H1: Cash Conversion Cycle (CCC) positive effect on financial distress.

\section{The Effect of Profitability to Moderate the Correlation of Cash Conversion Cycle on Financial Distress}

Profitability is one measure for the performance of a company.Profitability of a company shows the ability of a company in generating profits during a certain period at a certain level of sales, assets and capital stock (Hanafi, 2004). Increasingly losing companies increasingly high probability of financial distress (Andre, 2013). Negative relationship profitability of the company on the probability of financial distress in an enterprise supported by research conducted by Andre (2013) and Gobenvy (2014). This means that the higher profitability of the company the possibility of companies experiencing financial distress in the future will be smaller.
This research adds combination between variables by adding moderation variable. This is due to limitations in finding langung influence $\mathrm{CCC}$ against financial distress. Profitability is used as a moderating variable in this study.Profitability is chosen because every profit earned by the company from its production activities will be able to increase the company's assets and can be used in the company's operational activities. This shows the company has sufficient capital to finance the company's operations that will increasingly distanced the company from the possibility of being in financial distress.Based on the above description then the hypothesis to be tested as follows:

$\mathrm{H} 2$ : Profitability strengthen the influence of the financial distress CCC.

Based on the hypothesis that has been formulated, the research model can be seen in figure 1 as follows:

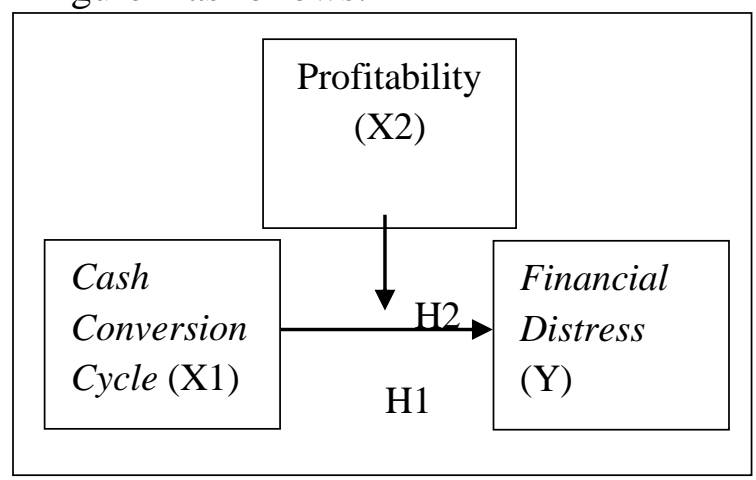

Figure 1 Research Model

\section{RESEARCH DESIGN}

\section{Types and Data Sources}

This research method uses quantitative methods that process data by collecting data of the numbers in the financial statements in accordance with the problems being studied is the cash conversion cycle and financial distressderived from the financial statements contained in the official website of Indonesia Stock Exchange (BEI) in the www.idx.co.id period 2010-2016. 
Operational Definition of Variables and Measurements

\section{Dependent Variable}

Financial distress variables used in this study a negative profit before taxes. Measurement of variables that are categorized as financial distress, a company that experienced a pre-tax loss for two consecutive years draws on research Widarjo and Setiawan (2009). Basic criteria for financial distress determination was based on the argument that if the company suffered a loss or negative earnings for two consecutive years signifies the company's performance is not good, and, if no corrective measures, the company can develop the condition worse, namely bankruptcy. The reason for using a profit before tax is to avoid the effect of using different tax rates across the study period.

\section{Independent Variable}

The independent variable in this study is the Cash Conversion Cycle(CCC). CCC is a measure of time owned by the company over the amount of funds invested in working capital. The CCC model includes: the inventory conversion period, the average receipt period and the deferred debt period (Brigham and Houston, 2014). The inventory conversion period is the average time it takes to convert raw materials into finished products and then sold. The average receivable receipt period is the average time to convert a receivable into cash. While the period of suspension of debt is the average time between the purchase of raw materials with the time of payment.

Cash Cash Conversion (CCC) can be calculated based on the inventory conversion period, the period of receivables and debt suspension period (Brigham and Houston, 2014).

Cash conversion cycle formula:

Cash Conversion Cycle $=$ number of days of accounts receivable + number of days of inventory - number of days of accounts payable
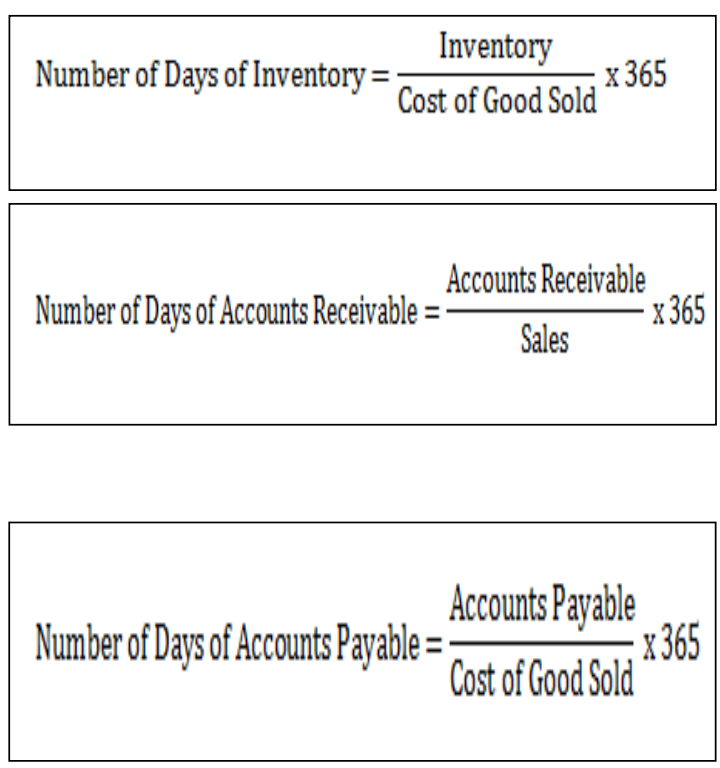

Source: Brigham and Houston, 2014

\section{Moderate Variable}

Moderate variable is variable that influence (strengthen or weaken) the relationship between independent variables and dependent variables. In this study profitability becomes a moderation variable. Profitability is the company's ability to earn profits (Kartini and Arianto, 2008). Profitability is chosen because every profit earned by the company from its production activities will be able to increase the company's assets and can be used in the company's operational activities. This shows the company has sufficient capital to finance the company's operations that will increasingly distanced the company from the possibility of being in financial distress.

The moderation variable in this research is profitability. Measurement of variables using the Return On Asset (ROA). ROA measures the company's ability to generate net income based on asset levels. A high ratio shows the efficiency and effectiveness of improved asset management. 
Formula:

$$
\text { Return On Asset }=\frac{\text { Net Profit }}{\text { Total Assets }}
$$

Tabel 1 Simbol Dan Pengukuran Operasional Variabel

\begin{tabular}{|c|c|c|}
\hline Variable & & \\
\hline & Symbol & Measurement \\
\hline $\begin{array}{l}\text { Financial } \\
\text { Distress }\end{array}$ & FD & $\begin{array}{l}\text { Negative profit before } \\
\text { tax }\end{array}$ \\
\hline $\begin{array}{l}\text { Cash } \\
\text { Conversion }\end{array}$ & $\mathrm{CCC}$ & $\begin{array}{l}\text { Number of Days of } \\
\text { Inventory }+ \text { Number of }\end{array}$ \\
\hline Cycle & & $\begin{array}{l}\text { Days of Accounts } \\
\text { Receivable - Number } \\
\text { of Days of Accounts } \\
\text { Payable) }\end{array}$ \\
\hline Profitability & ROA & Net Profit/Total Assets \\
\hline
\end{tabular}

Source: Summarized from various sources

Sample

Object of research

This study uses secondary data as the main data source. Secondary data were obtained from the publications issued by the Indonesia Stock Exchange through the official website www.idx.co.id. Periods of research data includes data years 2010-2016 were deemed sufficiently representative to predict financial distress because at that period of pressure for companies large enough sample after the global crisis of 2008, which allows for the occurrence of financial difficulties in the manufacturing sector in Indonesia.

Sample selection based on several criteria: (a) Manufacturing-based companies listed on Indonesia Stock Exchange 20102016 period. (b) Manufacturing companies that do not undergo delisting in the period 2010-2016. (c) the Company for 2 years in a row suffered loss before taxes as a group of companies categorized as financial distress because it is considered the company has decreased its financial condition or losses. (D) The manufacturing company shall issue a complete financial report for the period of 2010-2016. (E) Companies that use the rupiah-denominated financial statements for the period 20102016. Total population of financial statements as much as 866. Samples that meet the predefined criteria of 36 .

\section{Data Processing Technique}

This research take some steps in managing the data that has been collected from the Indonesia Stock Exchange website, that is determining the variables that will be included in excel, tabulating into formulas that have been determined by the researchers, then processed using the help of SPSS 17 program.

\section{Data Analysis Technique}

The data analysis technique used in this research is linear regression analysis which will be processed with the help of SPSS 17 program. To perform the regression analysis, the data must fulfill the classical assumption.

\section{Descriptive Statistic}

The descriptive statistic is used to describe the research data. The research data includes the mean, maximum, minimum, and standard deviation. Regression analysis is used to examine the effect of one variable with another variable.

\section{Hypothesis Testing}

Analysis of the data used in this study is a cross section data regression analysis. Model equation of regression analysis in this research is as follows:

$\mathrm{FD}=\alpha+\beta \mathrm{CCC}+\varepsilon \ldots \ldots \ldots \ldots \ldots \ldots \ldots \ldots . .(\mathrm{H} 1)$

$\mathrm{FD}=\alpha+\beta_{1} \mathrm{CCC}+\beta_{2} \mathrm{ROA}+\beta_{3} \mathrm{CCCxROA}+\varepsilon \ldots .(\mathrm{H} 2)$

Keterangan:

$\begin{array}{ll}\alpha & =\text { Constants } \\ \beta, \beta_{1}, \beta_{2}, \beta_{3} & =\text { Regression Coefficients } \\ \text { FD } & =\text { Financial Distress } \\ \text { CCC } & =\text { Cash Conversion Cycle } \\ \text { CCCxROA }= & \text { Moderation between CCC } \\ & \text { to Financial Distress } \\ \varepsilon & =\text { Standard Error }\end{array}$


The significance level $(\alpha)$ used is $5 \%$ (0.05). Criteria for acceptance and rejection of the hypothesis is based on the significance of the p-value(probability value). If the $\mathrm{p}$-value (significance) $>\quad \alpha$ (5\%), then the hypothesis is rejected. Conversely, if the p-value $<\alpha(5 \%)$, then the hypothesis is accepted.

\section{RESULTS AND DISCUSSION Descriptive Statistics}

Descriptive statistics can be seen in table 2 as follows:

\section{Table 2. Descriptive Statistics}

Source: Data processed with SPSS 17.0

In table 2 it can be seen the amount of data used in this study is 36 sample data. This study examined the independent variable is the cash conversion cycle that is measured by summing the period of inventory and receivables and reduced debt suspension period, the dependent variable is financial distress was measured with negative earnings before taxes and moderating variables were measured using ROA.

Based on descriptive statistics in table 2 it can be concluded that the financial distress had an average value of 23.330 million. From the overall sample indicates the maximum value for the variable financial distress of 690.000 and the lowest value of 0,00 with a standard deviation of 1,70 . The cash conversion cycle of the sample companies during the 20102016 period shows an average grade of 14,18 . The minimum value in the cash conversion cycle shows 0,00 while the highest cash conversion cycle is 19.88. Profitability variables in the form of ROA ratio shows the average of $-0,19$, the minimum ROA value of -3.46 and the maximum ROA is 0.00 with the standard deviation of ROA of 0,57 . The standard deviation of all variables close to 0 indicates a good result because the smaller the standard deviation value the smaller the sample data.

\section{Hypothesis Testing}

In this research has done the classical assumption test before hypothesis testing. From the results of the test, it can be concluded that the research data has been normally distributed, free from heteroscedasticity problem and there is no significant multicollonierity problem. This research does not perform autocorrelation test because the data used is cross section data.

\section{Hypothesis 1}

$\begin{array}{lccccl}\text { Variabel } & \text { N } & \text { Min } & \text { Max } & \text { Mean } & \begin{array}{l}\text { Standard } \\ \text { Deviation } \\ 1,70\end{array} \\ \begin{array}{l}\text { SQRT_Fina } \\ \text { ncial }\end{array} & 36 & 0,00 & 690.000 & 23.330 .000 & \\ \begin{array}{l}\text { Distress } \\ \text { SQRT_Cash }\end{array} & 36 & 0,00 & 19,88 & 14,18 & 4,63 \\ \begin{array}{l}\text { Conversion } \\ \text { Cycle }\end{array} & & & & & \\ \text { Profitability } & 36 & -3,46 & 0,00 & -0,19 & 0,57\end{array}$

The first hypotesis proposed in this study stated that the increase inte CCC will increase the probability of financial distress companies. The result of the analysis can be seen in table 6 as follows:

$\mathrm{FD}=17.458,80+15.220,23 \mathrm{CCC}$

Tabel 3. The Result of First Hypothesis (H1)

\begin{tabular}{lccc}
\hline Variable & Coefficient & Sig. & $\begin{array}{c}\text { Sig. } \\
\text { divided by } \\
2\end{array}$ \\
\hline Constant & $17.458,80$ & 0,840 & 0,420 \\
SQRT_CCC & $15.220,23$ & 0,012 & $0,006^{* *}$ \\
\hline R-Square & 0,171 & \\
Adjusted R- & 0,147 \\
Square & \\
**Significance at $\alpha=5 \%$ \\
Source: Data processed with SPSS 17.0 \\
Based on the above table it can be seen \\
that independent variables are CCC \\
significantly affect the dependent variable in \\
the form of financial distress at a level of
\end{tabular}


$95 \%$. This is evidenced by a significance of 0.006 (smaller than $\alpha=5 \%$ ). A positive sign in the variable coefficient indicates that the longer the cash conversion cycle, then the probability of financial distress is increasing. The value of $\mathrm{R}^{2}$ of 0.171 indicates that the CCC was able to explain the probability of financial distressby $17.1 \%$, while the remaining $82.9 \%$ is explained by other factors outside the model.

This result is consistent with Ebben and Johnson (2011) research which states that more efficient $\mathrm{CCCs}$ indicate a more liquid state of the enterprise, smaller equity financing and higher return on capital. Gul, et al.(2013), Yazdanfar and Ohman (2014), and Kamau and Ayuo (2014) had the same result, studies show that the cash conversion cycle effect on company performance as measured by the level of profitability.

The shorter cash cycle will get better, because the embedded cash will be less. Accelerated cash inflows and cash expenditures will be slowed causing cash availability, the greater (Hanafi, 2004). This of course will increase the capital of the company in operational activities. The availability of sufficient working capital will avoid the company of those risks that will lead to financial difficulties. A wrong decision on capital structure will result in high capital costs (Murhadi, 2013). The most direct impact can be felt is the ability of the company meet its short term obligations and will ultimately have an impact on the likelihood of financial distress.

By knowing the state of the company's capital structure, the managers will know how the company's prospects going forward. CCC can give a signalto the managers in making decisions. CCC long demonstrated a high capital attachments that will reduce the availability of liquid capital in the company and, if allowed to drag certainly will affect the company's operations. Managers are expected to take a decision such as: process and sell the goods more quickly, accelerate collection of accounts receivable, and slow down payment so that the $\mathrm{CCC}$ would be more efficient. Efficient CCC will providesignal positively to the company's internal and external parties.

\section{Hypothesis 2}

The second hypothesis proposed in this study stated that profitability is able to strengthen the influence of the CCC against financial distress. This hypothesis can be supported if the value of the significance of interaction variables indicate the value of $<0.05$ and can not be supported otherwise. Moderating influence can strengthen or weaken the dilhat of changes in the value of $\mathrm{R}^{2}$ before and after inserted moderating variable. The results of the analysis are shown in Table 7 as follows:

$\mathrm{FD}=110.079,67+6.602,99 \mathrm{CCC}+1,03 \mathrm{ROA}-$ 80.480,44CCCxROA

\section{Tabel 4. The Results of Second Hypothesis (H2)}

\begin{tabular}{lccc}
\hline Variable & B & Sig. & $\begin{array}{l}\text { Sig. } \\
\text { divided } \\
\text { by 2 }\end{array}$ \\
\hline Constant & $110.079,67$ & 0,215 & 0,108 \\
SQRT_CCC & $6.602,99$ & 0,283 & 0,142 \\
ROA & 1,03 & 0,052 & 0,026 \\
CCCxROA & $80.480,44$ & 0,031 & $0,016^{* *}$ \\
\hline R-Square & 0,171 & & \\
(Awal) & & & \\
R-Square & 0,429 & & \\
(Akhir) & & & \\
**Significance at $\alpha=5 \%$ & & \\
Source: Data processed by SPSS 17.0
\end{tabular}

Based on the above table it can be seen that the variable profitability able to moderate the influence of the CCC againstfinancial distress. This is evidenced by the level of singnifikansi 0,016 (less than $\alpha=5 \%$ ). The value of $\mathrm{R}^{2}$ in the first 
regression of 0,171 , or $17.1 \%$, while after the second equation by including interaction variables rose to 0,429 or $42,9 \%$. So with the profitability of strengthening relations $\mathrm{CCC}$ against financial distress. The negative sign on the interaction variable coefficients indicate the presence of a negative relationship between profitability and financial distress. That is, the higher profitability of the company, the smaller the probability of financial distress .

CCC their profitability in relation to the financial distress will further strengthen CCC influence on profitability. It is drawn from the shorter cash conversion cycle and the higher profitability levels the lower the probability of financial distress . Profitability CCC trending negative effect on the financial distress can be caused by good asset management carried out by the management with the efficient management of working capital, resulting in a certain profit. Where any profit gained from the company's current asset management will be used for the operations of the company.Proper management of working capital that would deprive the company of the possibility that the company is unable to meet its maturing obligations (Murhadi, 2013). It will also impact on the probability of companies experiencing financial distress .

The results also support the agency theory, agency theory according to the company's operations is the duty agent. Therefore, agents are required to optimize the existing capital to increase profitability. Companies that have a profit is high, it can be said that the agent managed to take the best decisions in the management of the company. With profits high will be signal a positive for investors in order to attract investors to invest in the company, so the chances of companies experiencing financial distress will be smaller.

Analysis of the CCC can describe how the actions of agents in the operational management of the company. CCC is increasingly short period shows that entanglement in current assets is low, so the cash turnover is high. High cash turnover that resulted in the availability of cash in the company is high, so that companies are able to finance the daily operations, semkain smooth production process, and ultimately the company's profitability can be increased. CCC short describe the faster inventory turnover that will reduce the costs associated with excess inventory. CCC brief also shows that the turnover of receivables more quickly, this will reduce the risk of uncollectible receivables. Other than that,CCC brief also influenced their debt suspension period which could be an additional capital firms. Thus, with the proper capital management decisions will bring profit to the company and avoid the problem of financial hardship.

\section{CONCLUSION, LIMITATION, AND IMPLICATION \\ Conclusion}

The study was conducted with the aim to determine the effect of cash conversion cycle against financial distress with profitability as a moderating variable on manufacturing companies listed in Indonesia Stock Exchange (BEI) in the period 2010-2016. The author conducted sampling and there are 9 companies manufacturing the sample in the study with a total of 36 the number of research data research data. The research data is secondary data in the form of financial statements. Based on the analysis results can be concluded as follows:

a. There are significant cash conversion cycle on the probability of occurance of financial distress. The longer the cash conversion cycle, then the probability of financial distress of companies getting bigger.

b. Variable profitability able to moderate the influence of cash conversion cycle against financial distress. Prediction 
companies experiencing financial distress amplified by the variable profitability.

\section{Limitation}

The author found some limitations to this study. Some limitations are as follows:

a. The research sample was too small.

b. The study is limited to the CCC dependent variable without looking at the effect of the partial components contained in the CCC.

c. The author does not use a control variable.

\section{Research Implication}

The implication of this research is to the company, this result may be a reference to avoid the financial difficulties that could be causing the bankruptcy. Capital management company (cash conversion cycle management) is one effort that can be done to maintain the survival of the company. If the company can manage inventory, receivables and debt suspension appropriately, then the increase in profitability will be achieved and it will certainly keep the company out of financial distress . For further research, this study can be used as a reference for further research.

\section{Suggestion}

Based on the limitations of the problems described above, there are some suggestions for future research as follows:
a. Adding samples by using a proxy that is different to predict financial distress.
b. Research conducted partially on CCC variable.
c. Future studies may use control variables such as the size and age of the firm to reduce the presence of othe rfactors that interfere with research.

\section{REFERENCES}

Almilia, L. S. (2003). Analisis FaktorFaktor yang Mempengaruhi Kondisi
Financial Distress pada Perusahaan Manufaktur uyang Terdaftar di Bursa efek Indonesia. Simposium Nasional Akuntansi IV, (hal. 546563). Surabaya.

Almilia, L. S. (2006). Prediksi Kondisi Financial Distress Perusahaan GoPublic Dengan Menggunakan Analisis Multinomial Logit. Jurnal Ekonomi dan Bisnis, Vol. XII, Hal. 1-26.

Almilia, L. S., \& Kristijadi, E. (2003). Analisis Rasio Keuangan Untuk Memprediksi Kondisi Financial Distress Perusahaan Manufaktur Yang Terdaftar Di Bursa Efek Indonesia. Jurnal Akuntansi dan Auditing Indonesia (JAAI), Vol. 7, Hal. 1-27.

Almilia, L. S., \& Silvy, M. (2003). Analisis Faktor-Faktor Yang Mempengaruhi Status Perusahaan Pasca IPO Dengan Analisis Multinomial Logit. Jurnal Ekonomi dan Bisnis Indonesia, Vol. 18, Hal. 374-390.

Andre, O. (2013). Pengaruh Profitabilitas, Likuiditas, dan Leverage Dalam Memprediksi Financial Distress. pp. 1-20.

Benardi, B., \& Bakara, M. V. (2012). Mengukur Cash Conversion Cycle Perusahaan Terbuka Operator Telekomunikasi Seluler di Indonesia Dalam Keterkaitannya Dengan Kinerja Pengelolaan Modal Kerja. Jurnal Telekomunikasi dan Komputer, Vol. 3, Hal. 27-48.

Brigham, E. F., \& Houston, J. F. (2014). Essentials of Financial Management (3rd ed.). Singapore: Cengage Learning Asia Pte Ltd.

Ebben, J. J., \& Johnson, A. C. (2011). Conversion Cycle Management in Small Firms Relationships with Liquidity, Invested Capital, and Firm Performance. Journal of Small Business and Enterpreneurship, pp. 381-396. 
Gobenvy, O. (2014). Pengaruh Profitabilitas, Financial Leverage dan Ukuran Perusahaan Terhadap Financial Distress Pada Perusahaan Manufaktur yang Terdaftar di Bursa Efek Indonesia Tahun 2009-2011. pp. 1-16.

Gul, e. (2013). Working Capital Management and Performance of SME Sector. European Journal of Business and Management, Vol. 5, pp. 60-68.

Hanafi, M. M. (2004). Manajemen Keuangan. Yogyakarta: BPFEYogyakarta.

Indonesia, B. R. (2009). Krisis Finansial Global dan Dampaknya Terhadap Perekonomian Indonesia. Outlook Ekonomi Indonesia, 1-101.

Jensen, C. M., \& Meckling, H. W. (1976). Theory of The Firm: Managerial Behaviour, Agency Costs and Ownership Structure. Journal of Financial Economics, Vol. 3, pp.

Kamau, D., \& Ayuo, A. (2014). The Effects of Working Capital Management On Organizational Performance - A Surveyo of Manufacturing Firms in Eldoret Municipality. Research Journal of Finance and Accounting, pp. 72-80.

Kartini, \& Arianto, T. (2008, Januari). Struktur Kepemilikan, Profitabilitas, Pertumbuhan Aktiva dan Ukuran Perusahaan Terhadap Struktur Modal pada Perusahaan Manufaktur. Jurnal Keuangan dan Perbankan, Volume 12(NO.1), Hal. 11-21.

Madugba, J. U., \& Ogbonnaya, A. K. (2016). Working Capital Management And Financial Performance: Evidence from Manufacturing Companies in
Nigeria. European Journal of Accounting, Auditing and Finance Research, Vol.4, pp. 98-106.

Murhadi, W. (2013). Manajemen Modal Kerja dan Profitabilitas Di Bursa Efek Indonesia.

Ross, S. A. (1977). The Determination of financial Structure: The IncentiveSignalling Approach. The Bell Journal of Economics, Vol. 8, pp. 23-40.

Saleh, A., \& Sudiyatno, B. (2013). Pengaruh Rasio Keuangan Untuk Memprediksi Probabilitas Kebangkrutan Pada Perusahaan Manufaktur Yang Terdaftar Di Bursa Efek Indonesia. Dinamika Akuntansi, Keuangan dan Perbankan, Vol. 2, Hal. 82-91.

Widarjo, W., \& Setiawan, D. (2009, Agustus). Pengaruh Rasio Keuangan Terhadap Kondisi Financial Distress Perusahaan Otomotif. Jurnal Bisnis dan Akuntansi, Vol. 11, Hlm. 107109.

Yazdanfar, D., \& Ohman, P. (2014). The Impact of Cash Conversion Cycle on Firm Profitability: An Empirical Study Based on Swedish Data. International Journal of Managerial Finance, Vol. 10, pp. 445-452. 